\title{
Legislative Constituency Project in Nigeria: Implication for National Development
}

\section{Patrick Nnadozie Udefuna}

\author{
National Institute for Legislative Studies, \\ National Assembly Abuja \\ patrickudefuna@yahoo.com
}

\section{Fadila Jumare}

National Institute for Legislative Studies, National Assembly Abuja

Francis Ojo Adebayo

National Institute for Legislative Studies, National Assembly Abuja.

\begin{abstract}
The Greek philosopher Aristotle averred that state exists for public goods and continues to exist for the greater good of humanity. Democracy on the other hand gives people opportunity to determine how they are governed. Naturally, the electorate or body of Nigerian masses look up to government for democracy dividends. The Nigerian National Assembly in response to the yearnings of their constituents for development/ federal presence demanded and got "Constituency Project" fund. Since the inception of constituency project in Nigeria there have been misconceptions, misinterpretations and judgement of the constituency project administration. This and indeed some other factors have painted the hallowed chambers of National Assembly in bad light. Therefore, this paper seeks to find out the origin, management etc. of constituency projects in Nigeria. It adopts desk research method; drawing data mainly from secondary source and adopts analytical research in arriving at finding. It found that members of the National Assembly merely identify the needs of the constituents and recommend same to the executive during budgeting. Ultimately, they have no direct control over their implementation; hence the award, financing and supervision of constituency projects are the preserves of appropriate agencies other than the National Assembly. Findings also show that other democracies have similar arrangements in place.
\end{abstract}

\section{Background}

In any democratic setting, there may either be presidential or parliamentary system of government, whereby the executive power is held by executive President or Prime Minister as the case may be. Nigeria, in 1989 adopted the Presidential system, with the legislative, executive and judicial functions performed by three distinct but coordinate arms of government. Government policies and programmes are executed in accordance with laid down rules and procedures for the benefits of individuals and the country as a whole. Constituency project is one very important issue in Nigerian democracy since the inception of the fourth republic (in 1999).

The vexed issue of constituency project savoured by the federal lawmakers since 2001 had always been controversial, though it had not attracted much attention until 2009 when the matter came up among Senators during one of their closed-door sessions. According to Tunji (2010), the concept of the constituency projects was first introduced during the early administration of former President Olusegun Obasanjo in 1999, and the controversies trailing it was not new. The leadership of the National Assembly had approached the executive (under Obasanjo) for approval of constituency projects. Their demand was in apparent response to frequent demands of their Constituents for the dividends of democracy. The Executive saw reasons with the legislators and approved constituency funds for them. However, from the start, Senators received N5million each, while each member of the House of Representatives got N3million as constituency allowance. Arguably, these payments were not captured in the budget. However, one of the 
controversies that trailed the handling of the projects arose from the lack of consensus or agreement among members of the House of Representative and Senators from each Senatorial district on a set of projects to be implemented in their respective constituencies.

It is no news that there are lots of loopholes in Nigeria's Presidential system of Government; such loopholes are known to have been exploited by corrupt politicians in defrauding the nation. The nation's political landscape is saturated with countless cases of corruption. Unfortunately, none of those cases has served as a deterrent to others (Okwoche 2012). The level and pervasiveness of corruption has attracted public odium and condemnation to the political class especially, the members of the National Assembly. Thus, this paper attempts to examine issues anchored on constituency project and who appropriates the constituency project funds, etc. Research project on the 'Best Practices' in the Management, Structures and Processes of Constituency Project and sought to establish what the good constituencies had done differently by identifying 'Best Practices' in constituency project implementation that could be replicated in other constituencies. It adopts descriptive and content analytical format.

\section{The Rationale behind Constituency Project}

Nigeria operates bi-cameral Parliamentary/ Legislative system, which consists of two houses: The Senate and the House of Representatives. However, unicameral system is in place at the state and local government levels. Elections into national and state assemblies are held every four years to elect a total of 360 members of the House of Representatives, who represent the Nation's 360 Federal Constituencies 109 Senators. (Three Senator per state and one from FCT) (Okon, 2004). The primary reason for establishing any government is to provide public good for the greater number of people through good governance. In the case of Nigeria, the people were hungry for democracy dividends and demanded same from their elected representatives. Perhaps the constituency project is a response to the yearnings of Nigerians for democracy and its dividends.

Constituency projects were created to ensure a minimum presence of government in every constituency by having some grass-roots projects sited in each, during the budgeting process. Legislators were merely required to identify projects which they wished to be sited in their constituencies for inclusion in the budget, with a financial ceiling for the budgetary provisions for such projects in each constituency. The 1999 Constitution gives power to the National Assembly to appropriate funds for government spending as highlighted in section 80 (2, 3 and 4). Senator Femi Okuronmu argued that the rationale behind the introduction of constituency project is:

To ensure a minimum presence of government in every constituency by having some grass-roots projects sited in each one, during the budgeting process... Legislators were merely required to identify projects which they wished to be sited in their constituencies for inclusion in the budget, with a financial ceiling for the budgetary provisions for such projects in each constituency. The award of contracts for, and the supervision and payments for such contracts were left completely in the hands of the appropriate executive agencies of government. (Okuronmu, 2009).

Senator Ayogu Eze corroborated the position above, he argued, "Our role is simply to identify the projects for our constituency while the Executive arm of government will identify the contractor to execute the project" (cited in Tunji, 2010). The Constitution of the Federal Republic of Nigeria, 1999 furnishes the National Assembly with the power to appropriate funds for government spending as captured in section 80 (2, 3 and 4). According to the Deputy Senate President, Ike Ekweremadu, the concept of constituency project came up as a result of the need to ensure equitable distribution of infrastructure and that every part of the country has a proper representation, in the House of Representatives and in the Senate. Ekweremadu argued that this is due to the fact that there will be rope sided development in the country, if governors and senators are allowed to decide where projects should be cited. As a result, all the representatives usually come up with what their constituents want (Anyanate, E. 2009).

It is deducible from the foregoing, that the concept of constituency project cropped up as a result of the need to ensure equitable and even distribution of infrastructure/ development. Ensure adequate representation of every part of the country in the House of Assembly, in the House of Representatives and in the Senate. However, parliamentarians merely recommend programmes and projects to be cited in their constituencies based on the needs and demands of their constituents. The award of contracts and the supervision and payments for such contracts are completely in the hands of the appropriate executive agencies of government.

On the other hand, a preponderance of the Nigerian masses views the concept of constituency project, as another conduit pipe through which the nation's treasury is being drained. For instance former President Olusegun Obasanjo 
accused Senators and members of the House of Representatives of corruption through the padding of federal budgets and collection of unjustifiable allowances that amount to billions of naira. President Obasanjo, who spoke in Abuja (in 2010) at a retreat for Niger State Senior Civil servants, alleged that the National Assembly members insert items into the budget, which are not actually required by ministries, and connive with contractors in the execution of constituency projects by taking kick-backs and at the same time turn around to accuse others of corruption. He also decried the huge cost of maintaining federal lawmakers, disclosing that it cost the federal government more than N250 million annually per head (Daily Trust, Monday, August 16 $6^{\text {th }}, 2010$ ).

There is the notion that there is hardly any concrete accomplishment by the federal lawmakers proportionate to and commensurate with their outrageous salaries and allowances. Government spends huge sums of money hosting federal legislators. Yet, very insignificant number of bills and motions are passed to justify these allowances. In two legislative years, for instance, no bills other than appropriation bills were passed. It is now apparent that those who should ordinarily be assets to democracy have instead become a huge drain pipe to the democratic project at a time when more of those they represent have fallen into penury (Daily Trust Editorial, Monday, 16 August 2010). This school are also of the view, that most representatives visit their constituencies only during electioneering campaign. Thereafter, they abandon most pledges and promises made to their constituencies and constituents.

\section{Cross Country Experience}

Parliamentary involvement in grassroots projects and in community development has been growing in many developing countries, including Kenya, Pakistan, India, Uganda, Bhutan, Jamaica and Papua New Guinea and Nigeria. One policy tool for this involvement is Constituency Development Funds (CDFs), which dedicate public fund to benefit specific political subdivisions through allocations and/or spending decisions influenced by their representatives in the national parliament (Baskin, et al 2010). The management of CDFs includes goals and size of the funds; the structure of decision making on the use of the funds at all stages of implementation; oversight of CDF operations; and the relative influence of different individuals and groups in making policy. According to Baskin, et al (2010) Constituency Development Funds are akin to the venerable U.S. congressional allocations generally known as "pork barrel," "earmarks" or "member items" in national and state-level policy making. The management of CDFs has sometimes been controversial because they raise fundamental questions about the efficacy of government service delivery. It indicates the extent to which such service delivery can be made accountable, the role of legislators in selecting development priorities, and how public participation in policy making can be made more meaningful.

The major aim of the CDF is redistributing national resources to the community to improve rural economy, alleviate poverty, create employment and improve the standard of living of Kenyans. It also ensures that services and facilities are closer to the people as a means of reducing poverty. It is a complementary effort aimed at boosting existing funds (such as the Local Authorities' Transfer Fund, Bursary Fund, Fuel Level Funds and Roads Maintenance Fund) directed at the rural/ community level.

In Kenya, the Constituency Development Fund (CDF) is a strategy for the devolution of resources and attaining of even development. It was also a strategy for attaining enhanced people's participation and power in decision-making processes; promote good governance, transparency and accountability. However, various issues and concerns have been raised regarding the CDF processes and structures and community participation in decision-making in the administration, management, monitoring and evaluation of the fund in various Constituencies. Some Constituencies have been termed as good Constituencies while others bad constituencies based on Constituency Development Fund implementation level.

It is however, of great importance to note that Constituency Development Fund (CDF) was established through the Constituency Development Fund Act of 2003. Analysts see it as one of the laudable contributions of the National Rainbow Coalition (NARC) Government of Kenya to democratic growth in the country. In Kenya, for example the CDF is an annual budgetary allocation by the Central Government to each of the country's parliamentary constituencies Kimani, F. et al (2009). While there are several rules that govern the utilization of the Fund to ensure transparency and accountability, decisions over the utilization of the funds are supposed to be mainly by the Constituents.

Efforts to anchor the CDF on a legal foundation were initiated in 1999 when the first motion on Constituency Development Fund was moved in parliament. The motion prayed the government to devote $5 \%$ of government revenue to community-based projects. The motion was passed but then the government did not implement it. According to Mwangi S. K. (2005) in 2001/2, a caucus of Members Parliament (MPs) was constituted to lobby the Minister for Finance to allocate the $5 \%$ to community based projects. The initial $5 \%$ captured in motion was further amended/ reviewed 
downwards to 2.5\% through the collaborative effort of Parliament and the Ministry of Finance. In furtherance of giving every legal backing to the CDF, the Constituency Development Fund Bill was drafted and presented to Parliament in April 2003. The bill was passed in November 2003, thus establishing the Constituencies Development Fund (CDF) through an Act of parliament. As such, 2.5\% of all the government ordinary revenue collected every year is paid into the fund (Kimani, F. et al 2009, Mwangi, S. K. 2005). Kimani, F. et al (2009) further argued that the CDF has four management organs, namely:

(a) The Constituencies Fund Committee: This is a committee made up of 11 selected Parliamentarians and the Clarks of the Kenyan National Assembly, charged with the responsibility of:

$\checkmark$ Considering and recommending to Parliament any matter requiring action by the National Assembly;

$\checkmark$ Considering referenced project proposals submitted from various Constituencies through the Board;

$\checkmark$ Considering and reporting to Parliament names of persons required to be approved under the Act;

$\checkmark$ The link between the CDF Board and National Assembly;

$\checkmark$ Overseeing the implementation of the CDF Act, 2003 and its subsequent amendments (CDF Amendment Act 2007);

$\checkmark \quad$ Overseeing the policy frame work and legislative matters that may arise in relation to the Fund;

$\checkmark$ Continuously review the frame work set out for the efficient delivery of development programmes financed through the Fund (Kimani, F. et al, 2009).

(b) The Constituency Development Fund Board: This is the national organ to oversee CDF implementation. Specifically the Board mandate according to Kimani, F. et al, (2009) include to:

* Ensure allocation and disbursement of funds to every Constituency;

* Ensure prudent management of the Fund;

* Receive and discuss annual reports and returns from the Constituencies;

* Ensure the compilation of proper records, returns and reports from the Constituencies;

* Receive and address complaints and disputes and take any appropriate action;

* Ensure timely submission to Parliament of various returns, reports and information as required;

* Review, scrutinize and approve Project Proposals from the Constituencies that are consistent with the Act;

* Refer Disapproved Project Proposals or any other policy issue, from the Constituencies with adequate reasons, to the Constituency Fund Committee for direction and consideration.

(c) The District Project Committees: This organ coordinates the implementation of projects financed through the Fund. It ensures that no duplication of projects occur particularly where it is prudent to combine efforts on projects designed to benefit a large section or sector of a community traversing several constituencies in each parliamentary district.

(d) The Constituencies Development Fund Committees: It is constituency based and comprises of a minimum of 12 people and a maximum of 15 people. The membership consists the following;

$>$ An elected member of Parliament;

$>$ Two councilors in the constituency;

$>\quad$ One district officer in the constituency;

Two persons representing religious organizations in the constituency;

$>$ Two men representatives from the constituency;

$>$ Two women representatives from the constituency;

$>$ One person representing the youth from the constituency;

$>$ One person nominated from among the active NGOs in the area if any;

$>$ A maximum of three other persons from the constituency such that the total number does not exceed fifteen;

$>$ An officer of the Board seconded to the Constituency Development Fund Committee by the Board, who shall be ex-officio.

The CDF places high premium projects from the locations. The list of priority projects is then submitted to parliament by the legislator representing affected district. This committee is also saddled with the management and implementation of CDF projects at the constituency level. Constituency Development Fund members enjoy a three year term of office. This term is renewable or upon the appointment of a new committee in a manner provided for in the CDF Act, whichever comes first. Approved proportions of funding include; administration - 3\%, education bursary $-15 \%$, emergency reserve $-5 \%$ and operation and maintenance of vehicles, equipments and machinery $-3 \%$. Others are sports activities $-2 \%$, monitoring and evaluation $-2 \%$ and environmental $-2 \%$

In Uganda, the Constituency Development Fund (CDF) is an outcome of series of meetings between the Presidency and Members of the Ugandan 7th Parliament (MPs). The Presidential pledge made to Members of the 
National Assembly, which was intended to relieve Parliamentarians of the pressures of their Constituents in regard to the promised and other development projects. Like in Kenya, Constituency Development Fund in Uganda involves a sum of money mapped out annually for the development of each legislative district. The concept of Constituency Development Fund (CDF) was first used in Uganda during the budget proposals for the Financial Year 2005/ 2006. After a presentation of a Ministerial Statement before the Legal and Parliamentary Affairs Committee, a plenary session of Parliament on 9th September 2005 adopted the proposal for a CDF (UDN, Briefing Paper on the Constituency Development Fund, May 2007). The sum of 2.95 billion shilling was recommended by the Ugandan national Parliament to be earmarked for MPs and that the said sum should be releases expeditiously. Unlike Kenya, there is no comprehensive law governing the management of CDF in Uganda. The Constituency development fund implementation committee ensures the following:

$>$ That every MP has to establish a Committee of 5 people composed of him/ herself as the Chairperson, a Secretary, a Treasurer and two other members for the purpose of handling this money;

$>\quad$ That the money would be released to the individual MP and the responsibility of accountability to the Accounting Officer (Clerk to Parliament) would lie with the MP;

$>\quad$ That the money for each Financial Year is accounted for within one year;

$>$ That the funds are invested on activities that directly increase household incomes and productivity; on interventions that can trigger rapid rural transformation and economic development; and on agro-processing and marketing of produce in the respective constituencies;

$>\quad$ That the money is not spent on development of infrastructure projects already under the Local Government initiatives or Central Government programmes or projects; and on political and/or religious activities.

The Clerk to Parliament releases the constituency development money to the personal accounts of the parliamentarians and holds MPs accountable for every fund released.

India has two CDF-style schemes: the Members of Parliament Local Area Development Scheme (MPLADS) at the national level and the Member of Legislative Assembly Local Area Development Fund (MLA-LAD) for the Legislative Assembly of each of India's 28 States. The MPLADS scheme was instituted in India in 1993 under the dominant national party, the Congress Party. Under the MPLADS, an equal amount is allocated annually to each single-member parliamentary constituency; the funds are to be used for "works of developmental nature with emphasis on the creation of durable community assets based on the locally felt needs." The Ministry of Statistics and Programme Implementation has overall responsibility for managing the funds. Each State government must designate a Nodal Department which is responsible for coordination with the Ministry and effective supervision (including physical inspection) of the work on site. The MPs recommend projects which are sanctioned by the District Authority who is directly responsible for implementation. The District Authority identifies the agency to be used to execute the project; this may be a local government, government agency or NGO. The District Authority is also responsible for enforcing the provisions of the guidelines with regard to admissible expenditure

Tanzania took the Kenyan practice of allocating $25 \%$ of the fund according to the poverty index and went further to include factors of geographical size and population in their allocation formula. According to Section 3 of the Act, $25 \%$ of the total amount will be divided equally between all constituencies (IBP, 2010). The remaining 75\% will be split between the constituencies as follows:

$>45 \%$ in relation to the constituency's population

$>20 \%$ in relation to the poverty margin, and;

$>10 \%$ in relation to the geographical size of the constituency.

Similar to Kenya, the Constituency Development Catalyst Committee (CDCC) for each constituency is convened and chaired by the MP. However it is limited to 6 members, including the District Planning Officer who serves as Secretary.

Table 1, below, shows the great National variation in the amount of money allocated to each MP in a CDF.

\begin{tabular}{|l|l|}
\hline Country & $\begin{array}{c}\text { Average } \\
\text { Allocated per MP (USD) }\end{array}$ \\
\hline Philippines & $\$ 4,270,001$ \\
\hline Bhutan & $\$ 43,000$ \\
\hline Solomon Islands & $\$ 140,000$ \\
\hline Kenya & $\$ 794,464$ \\
\hline Malaysia & $\$ 577,951$ \\
\hline Jamaica & $\$ 456,361$ \\
\hline
\end{tabular}




\begin{tabular}{|l|l|}
\hline India & $\$ 420,790$ \\
\hline Sudan & $\$ 317,543$ \\
\hline Pakistan & $\$ 240,000$ \\
\hline Malawi & $\$ 21,352$ \\
\hline Tanzania & $\$ 13,761$ \\
\hline Uganda & $\$ 5,187$ \\
\hline
\end{tabular}

However, in Nigeria it has been established that monies meant for the execution of Constituency projects in the country are not routed through the members of the National Assembly as being speculated. Hon. Mohammed Sani Takori (Gummi/Bukkuyum Federal Constituency) challenged the Presidency, and all finance and appropriation implementation related agencies to come out with documents and facts to prove that money for Constituency projects are routed through members of the National Assembly. He spoke in reaction to the face-off between the sixth National Assembly and the Governor of the Central Bank of Nigeria (CBN), Sanusi Lamido Sanusi. Sanusi alleged that 25 per cent of the federal over head budget goes to the National Assembly, as well as the public impressions that funds meant for Constituency projects are embezzled by the lawmakers (Turaki, 2010).

The former Attorney General of Zamfara State defended Constituency Project, by stating that no member of the National Assembly was involved in the handling of the funds for projects or the award of contracts and its execution and challenged the MDG office and the Ministry of Finance to prove him wrong.

The concept as described above looks convincing also the funds have in many ways achieved so much to lives of the Constituents. These can be achieved if the amount on these projects could be monitored. From what we understand, the Constituency project funds even exist at the State assembly level.

Given our national panache for back-dealings and little regard for accountability — the constituency project fund may be likened to an open vault begging to be misused or even looted if not properly followed-up.

\section{Conclusion}

The paper has been able to establish the fact that the constituency project is an idle move towards the devolution of resources and development. This will no doubt bring about even development and encourage popular participation in politics. The misconception about management of the Constituency project holds no water any more since it is now a definite fact that Nigerian Parliamentarians merely attract Government's attention and presence to their districts by recommending the Societal needs of their Constituents to the Government during budgeting. Various relevant MDAs oversee the award of contracts and their implementation as against the general misconception that the National Assembly members have been feeding fat on the Constituency project funds.

The Constituency project is not peculiar to Nigeria. There are similar mechanisms in other developing Countries. In Kenya, for instance the constituency development fund has been institutionalized in Kenya, Uganda, India and Tanzania. Instead of vilifying the National Assembly on the Constituency project, people should advocate for an institutional framework for the implementation of the Constituency projects as it is the case in Kenya.

Also, there is need for Constituency needs assessment prior to awarding contracts. Constituency ought to get what they need and not what the representative wants or what a few influential constituents request. Since these projects are intended to alleviate poverty, provide and/ or improve on already existing infrastructure, therefore, provision of these facilities and relief packages should sincerely serve its purpose unselfishly.

\section{References}

Anyanate, E. (2009), Constituency Projects- Is It Time To Scrap Them? Nigerian Village Square, online Newspaper, Sunday, 22 November 2009

Baskin, M., Haibo, L., Samrat B., and Ryan A. (2010), Constituency Development Funds (CDFs) as a Tool of Decentralized Development, Centre for International Development.

Daily Trust Editorial, Monday, 16 August 2010

International Budget Partnership (IBP) Open Budgets. Transform Lives. Constituency Development Funds: Scoping Paper, 18 January 2010

Kimani, F., Praxides, N., \& Bern ard N. (2009), Best Practices in Constituency Development Fund (Cdf), the Centre Collaborative Centre for Gender and Development 
Mwangi S. K. (2005), Efficiency and Efficacy of Kenya's Constituency Development Fund: Theory and Evidence. Economics. Working Papers. Paper 200542.

Okon, A. O (2004), Nigeria and a People's Constitution: The Imperative of Democracy and Change, Journal of Constitutional Development Volume 4, No.1 (p. 11-36). Centre for Constitutionalism and Demilitarisation (CENCOD).

senatorchukwumerije.net

Turaki, H. (2010) N/Assembly denies awarding constituency projects, Daily Trust Newspaper, December 6.

UDN, Briefing Paper on the Constituency Development Fund, May 2007. 